\title{
ASBTRAK \\ HUBUNGAN TINGKAT PENDIDIKAN DAN PENGETAHUAN IBU BALITA TENTANG DENGAN KEJADIAN ISPA PADA BALITA DIWILAYAH KERJA PUSKESMAS BONTOSIKUYU KABUPATEN KEPULAUAN SELAYAR
}

\author{
Nur Syamsi N.L \\ 0902028502 \\ Dosen tetap program studi DIII Keperawatan Sandi Karsa Makassar
}

Infeksi Saluran Pernapasan Atas adalah infeksi yang di sebabkan oleh mikro-organisme. Infeksi tersebut terbatas pada struktur-struktur saluran napas bagian atas termasuk rongga hidung, faring hingga laring.

Tujuan penelitian untuk mengetahui hubungan tingkat pendidikan dan pengetahuan ibu balita dengan kejadian Ispa pada balita diwilayah kerja Puskesmas Bontosikuyu Kabupaten Kepulauan Selayar. Penelitian ini merupakan penelitian deskriptif menggunakan metode cross sectional. Populasinya adalah Ibu yang memiliki balita yang berada berobat diwilayah kerja Puskesmas Bontosikuyu Kabupaten Kepulauan Selayar. Pengambilan sampel menggunakan teknik noprobability sampling didapatkan 30 Orang. Pengumpulan data dilakukan dengan kuesioner dan observasi langsung. Data diolah dan dianalisa dengan menggunakan komputer program microsoft excel dan program statistik (SPSS) versi 16.0.

Analisa data mencakup analisa univariat dengan mencari distribusi frekuensi, analisa bivariat dengan uji chi-square $(\alpha=0,05)$. Hasil analisa bivariat didapatkan uji Chi-square test pada variable ini adalah $\rho=0.06$, Sehingga menunjukan bahwa tidak ada hubungan antara tingkat pendidikan ibu dengan Kejadian ISPA Pada Balita diwilayah kerja Puskesmas Bontosikuyu Kabupaten Kepulauan Selayar. Hasil uji Chi-square test pada variable ini adalah $\rho=0.004$, Sehingga menunjukan bahwa ada hubungan antara tingkat pegetahuan Ibu dengan Kejadian ISPA pada Balita diwilayah kerja Puskesmas Bontosikuyu Kabupaten Kepulauan Selayar.

Kesimpulan dalam penelitian ini: tidak ada hubungan tingkat pendidikan ibu dengan Kejadian ISPA Pada Balita diwilayah kerja Puskesmas Bontosikuyu Kabupaten Kepulauan Selayar dan ada hubungan tingkat pengetahuan ibu dengan Kejadian ISPA Pada Balita diwilayah kerja Puskesmas Bontosikuyu Kabupaten Kepulauan Selayar. Saran: Hindari faktor resiko terjadinya ISPA pada balita dengan perilaku hidup sehat.

\section{Kata Kunci : Tingkat Pendidikan, Tingkat Pengetahuan dan Ispa}

\section{Pendahuluan}

Dalam GBHN, dinyatakan bahwa pola dasar pembangunan Nasional pada hakekatnya adalah Pembangunan Manusia Indonesia seutuhnya dan pembangunan masyarakat Indonesia. Jadi jelas bahwa hubungan antara usaha peningkatan kesehatan masyarakat dengan pembangunan sangat erat kaitannya, karena tanpa modal kesehatan niscaya akan gagal pula pembangunan kita. (Rasmaliah, 2004).

Pembangunan kesehatan bertujuan untuk meningkatkan derajat kesehatan masyarakat, sumber daya manusia serta kesejahteraan keluarga dan masyarakat pada umumnya. Usaha peningkatan kesehatan masyarakat pada kenyataannya tidaklah mudah oleh karena masalah ini sangatlah kompleks, terutama pada kelompok masyarakat resiko tinggi yaitu ibu dan anak, ibu hamil dan ibu meneteki serta anak bawah lima tahun. (Supartini, 2014).

Anak merupakan masa depan bagi pembangunan bangsa yang berhak atas pelayanan kesehatan secara individu. Disamping itu anak merupakan individu dalam proses tumbuh-kembang yang rentang terhadap berbagai jenis penyakit, mengingat anak memiliki daya tahan tubuh yang belum matur. Anak bukanlah miniatur orang dewasa, melainkan individu kebutuhannya masih bergantung pada orang tua secara keseluruhan. Orang tua terutama ibu diyakini sebagai orang yang paling tepat dalam memberikan perawatan pada anaknya. Ngastyah (1998\} menyatakan tujuan pelayanan perawatan rumah adalah meminimalkan biaya perawatan dan memberikan kesempatan kepada keluarga untuk berpartisipasi dalam merawat anggota keluarga guna mencegah terjadinya penyakit yang sama. (Ngastiyah, 1999).

Infeksi saluran pernapasan akut (ISPA) merupakan masalah serius di Indonesia dan hingga saat ini merupakan penyakit penyebab kematian dan kesakitan yang paling sering. Angka kematian menunjukan 20-30\% kematian bayi dan balita disebabkan karena ISPA. Diperkirakan 2-5 juta bayi dan balita di berbagai Negara setiap tahun meninggal karena ISPA. (Achmad, 2006).

Hasil konferensi internasional mengenai ISPA di cambera, Australia pada juli 1997, menemukan 4 juta 
bayi dan balita di Negara-negara berkembang meninggal karena ISPA. Diakhir tahun 2000, kematian akibat Pneumonia merupakan penyebab utama ISPA di Indonesia yang mencapai lima kasus diantara 1.000 bayi/balita. Artinya, $150 \mathrm{ribu}$ bayi/balita meninggal pertahunnya, atau 12.500 korban perbulan, atau 416 sehari atau 17 anak perjam atau seorang bayi tiap lima menit. (Achmad, 2006).

World Health Organitation (WHO) memperkirakan di Negara berkembang berkisar 30-70 kali lebih tinggi dari Negara maju dan diduga 20\% kematian anak disebabkan oleh ISPA. Di Indonesia setiap tahun terjadi sekitar 450.000 kematian balita, dan 33,33\% disebabkan oleh ISPA. (Depkes.RI, 2015).

Survey Kesehatan Rumah Tangga (SKRT) tahun 2013, kematian pada semua kelompok umur, ISPA berada diurutan pertama sebesar $32,2 \%$, disusul penyakit TBC dengan 9,6\% kematian kemudian diare dengan jumlah 7,4\% kematian. Sedangkan pada balita pola penyebab ini lebih tinggi lagi yaitu $30,8 \%$ kematian dan menduduki urutan pertama pola penyakit pada balita sebanyak 19,4\% per 100 balita (Dinkes Provinsi Sul-sel, 2013).

Menurut laporan tahunan PKM Bontisikuyu Kabupaten Kepulauan Selayar, penyakit ISPA menduduki peringkat pertama pada 10 penyakit terbesar. Tahun 2014 jumlah kasus ISPA adalah 68 orang dan di tahun 2015 mengalami peningkatan dengan jumlah kasus mencapai 111 orang sedangkan jumlah kasus ISPA pada bulan Januari-Agustus tahun 2016 adalah 130 orang, 190 orang (Laporan PKM Bontisikuyu, 2016).

Berdasarkan uraian diatas, penyakit ISPA merupakan penyakit dengan angka kesakitan yang tinggi, sehingga dalam penanganannya diperlukan kesadaran, baik dari masyarakat (keluarga) maupun petugas kesehatan terutama faktor-faktor yang mempengaruhinya. (Achmad, 2006)

Faktor-faktor yang berhubungan dengan kejadian ISPA antara lain, lingkungan, BBLR (berat badan lahir rendah), status imunisasi, tingkat pendidikan dan pengetahuan keluarga, serta malnutrisi (Depkes.RI, 2015).

Ditinjau dari tingkat pendidikan masyarakat bahwa dengan pendidikan dan pengetahuan yang dimiliki oleh keluarga, diharapkan dapat mengembangkan daya nalar dan dapat memberikan kemampuan baginya untuk bisa merawata anggota keluarga yang sakit guna tercapainya derajat kesehatan yang optimal. (Sabri, 2007)

\section{Tinjauan Pustaka}

\section{A. Tinjauan Umum ISPA}

\section{Pengertian ISPA.}

ISPA merupakan singkatan dari infeksi saluran pernafasan akut, istilah ini diadaptasi dari istilah dalam bahasa Inggris Acute
Respiratory Infections (ARI). Istilah ISPA meliputi tiga unsur yakni infeksi, saluran pernafasan dan akut, dengan pengertian sebagai berikut: Notoatmodjo, 2013).

Infeksi adalah masuknya kuman atau mikroorganisme ke dalam tubuh manusia dan berkembang biak sehingga menimbulkan gejala penyakit.

a. Saluran pernafasan adalah organ mulai dari hidung hingga alveoli beserta organ adneksanya seperti sinus-sinus, rongga telinga tengah dan pleura. ISPA secara anatomis mencakup saluran pernafasan bagian atas, saluran pernafasan bagian bawah (termasuk jaringan paru-paru) dan organ adneksa saluran pernafasan. Dengan batasan ini, jaringan paru termasuk dalam saluran pernafasan (respiratory tract).

b. Infeksi akut adalah infeksi yang berlangsung sampai dengan 14 hari. Batas 14 hari diambil untuk menunjukkan proses akut meskipun untuk beberapa penyakit yang dapat digolongkan dalam ISPA proses ini dapat berlangsung lebih dari 14 hari. (Sunaryo, (2014).

2. Etiologi

Penyakit ISPA dapat disebabkan oleh berbagai penyebab seperti bakteri, virus dan riketsia. ISPA bagian atas disebabkan oleh virus, sedangkan ISPA bagian bawah dapat disebabkan oleh bakteri dan virus. ISPA bagian bawah yang disebabkan oleh bakteri umumnya mempunyai manifestasi klinis yang berat sehingga menimbulkan beberapa masalah dalam penganannya. (Peduli kasih, 2013).

Etiologi ISPA terdiri dari 300 jenis bakteri, virus dan riketsia. Bakteri penyebab ISPA antaralain Genus streptokokus, Pneumokokus, Hemofilus, Bordetella dan Corinebacterium. Sedangkan virus penyebab ISPA antaralain golongan Miksovirus, Adenovirus, Koronavirus, Mikoplasma, Hervesvirus dll. (Didin, 2016).

Disamping beberapa penyebab ISPA secara langsung diatas, ada juga yang bersifat tidak langsung diantaranya

a. Tingkat pendidikan dan pengetahuan

Tingkat pendidikan seseorang mempengaruhi perilaku individu, makin tinggi tingkat pendidikan seseorang makin tinggi kesadaran dan pemahamannya tentang perawatan pada anggota keluarga yang mengalami gangguan kesehatan dan berupaya untuk 
tetap mempertahannkan status kesehatan yang lebih optimal.

b. Lingkungan

Lingkungan diartikan sebagai segala sesuatau yang berada disekitar kita yang dapat mempengaruhi kesehatan. Lingkungan yang buruk akan meningkatkan resiko seseorang terkena penyakit. Keadaan perumahan adalah salah satu factor yang menentukan keadaan hygiene dan sanitasi lingkungan, seperti yang dikemukakan WHO bahwa perumahan yang tidak cukup dan terlalu sempit mengakibatkan pula tingginya kejadian penyakit dalamj masyarakat.

c. Satatus gizi

Gizi merupakan bagian dari proses kehidupan dan proses tumbuh kembang anak, sehingga pemenuhan kebutuhan gizi secara adekuatturut menentukan status kesehatan anak. Angka kesakitan dan kematian sering dikaitkan dengan status gizi dari anak tersebut. Kesehatan gizi yang rendah kondisi daya tahan tubuh umum menurun, sehingga berbagai penyakit dapat timbul dengan mudah.

d. Berat badan lahir rendah

Berat badan lahir seorang anak normalnya 2500 gram atau lebih, sedangkan dikatakan Berat badan lahir anak rendah bila kurang dari 2500 gram. Anak-anak dengan berat badan lahir rendah mempunyai resiko kematian yang lebih tinggi dibanding dengan anak dengan berat badan normal ketika dilahirkan. Hal ini berkaitan dengan kondisi ibu sewaktu hamil.

e. Status imunisasi

Imunisasi adalah salah satu cara untuk mendapatkan kekebalan yang dimasukan kedalam tubuh seseorang agar tahan terhadap berbagai serangan penyakit. Semakin lengkap imunisasi anak, memungkinkan untuk terkena penyakit akan kurang bila dibandingkan dengan anak yang mendapatkan imunisasi tidak lengkap.

3. Gejala

Tanda atau gejala umum yang biasa ditemukan pada anak dengan ISPA antaralain batuk, pilek, demam, sesak napas dan sakit tenggorokkan dan ada tidaknya retraksi dinding dada. ${ }^{7}$

B. Tinjauan Tentang Perawatan ISPA di Rumah Anak adalah individu yang unik dan bukan orang dewasa mini. Disamping itu anak bukan hanya merupakan harta atau kekayaan orang tua yang dapat dinilai secara social ekonomi, melainkan masa depan bagi pembangunan bangsa yang berhak atas pelayanan kesehatan secara individu. Anak merupakan individu yang memiliki tingkat kebutuhan yang berbeda-beda dimana pemenuhan kebutuhan dasarnya masih bergantung pada keluarganya (orang tua) secara keseluruhan baik itu kebutuhan akan makan, minum, udara, dan eliminasi, secara psikologi juga anak membutuhkan cinta dan kasih sayang, serta rasa aman atau bebas dari ancaman. (Supartini, 2014).

Beberapa hal yang perlu dikerjakan seorang ibu untuk mengatasi anaknya yang menderita ISPA : (Depkes RI, 2014).

1. Mengatasi panas (demam)

Untuk anak usia 2 bulan samapi 5 tahun demam diatasi dengan memberikan parasetamol atau dengan kompres, bayi dibawah 2 bulan dengan demam harus segera dirujuk. Parasetamol diberikan 4 kali tiap 6 jam untuk waktu 2 hari. Cara pemberiannya, tablet dibagi sesuai dengan dosisnya, kemudian digerus dan diminumkan. Memberikan kompres, dengan menggunakan kain bersih, celupkan pada air (tidak perlu air es).

2. Mengatasi batuk

Dianjurkan memberi obat batuk yang aman yaitu ramuan tradisional yaitu jeruk nipis $1 / 2$ sendok teh dicampur dengan kecap atau madu $1 / 2$ sendok teh, diberikan tiga kali sehari.

3. Pemberian makanan

Berikan makanan yang cukup gizi, sedikitsedikit tetapi berulang-ulang yaitu lebih sering dari biasanya, lebih-lebih jika muntah. Pemberian ASI pada bayi yang menyusu tetap diteruskan.

4. Pemberian minuman

Usahakan pemberian cairan (air putih, air buah dan sebagainya) lebih banyak dari biasanya. Ini akan membantu mengencerkan dahak, kekurangan cairan akan menambah parah sakit yang diderita.

5. Lain-lain

Tidak dianjurkan mengenakan pakaian atau selimut yang terlalu tebal dan rapat, lebihlebih pada anak dengan demam. Jika pilek, bersihkan hidung yang berguna untuk mempercepat kesembuhan dan menghindari komplikasi yang lebih parah. Usahakan lingkungan tempat tinggal yang sehat yaitu yang berventilasi cukup dan tidak berasap. Apabila selama perawatan dirumah keadaan anak memburuk maka dianjurkan untuk membawa kedokter atau petugas kesehatan. 
Untuk penderita yang mendapat obat antibiotik, selain tindakan diatas usahakan agar obat yang diperoleh tersebut diberikan dengan benar selama 5 hari penuh. Dan untuk penderita yang mendapatkan antibiotik, usahakan agar setelah 2 hari anak dibawa kembali kepetugas kesehatan untuk pemeriksaan ulang

Beberapa faktor penyebab kematian maupun yang berperan dalam proses pertumbuhan dan perkembangan balita, yaitu (Achmad, 2006).

1. Diare

2. Penyakit yang dapat dicegah dengan imunisasi

3. Infeksi saluran pernapasan akut

Untuk itu kegiatan yang dilakukan terhadap balita antaralain, pemeriksaan pertumbuhan dan perkembangan fisiknya, pemeriksaan dan perkembangan kecerdasan, pemeriksaan penyakit infeksi, imunisasi, perbaikan gizi dan pendidikan kesehatan pada orang tua (Achmad, 2006).

\section{Tinjauan Tentang Balita}

Anak balita adalah anak yang berusia antara 1259 bulan dan merupakan generasi yang perlu mendapat perhatian disebabkan oleh beberapa hal, yaitu: (Mardianah, 2003).

1. Anak balita merupakan generasi dan modal dasar untuk kelangsungan hidup bangsa.

2. Anak balita amat peka terhadap penyakit.

3. Tingkat kematian balita masih tinggi.

Masalah kesehatan balita merupakan masalah nasional, mengingat angka kesakitan dan kematian pada balita cukup tinggi. Angka kesakitan mencerminkan keadaan yang sesungguhnya karena penyebab utamanya adalah yang berhubungan dengan factor lingkungan (perumahan, kebersihan lingkungan dan polusi udara), kemiskinan, pendidikan dan pengetahuan, kurang gizi, penyakit infeksi dan pelayanan kesehatan. (Notoatmodjo, 2013).

\section{Tinjauan Tentang Pendidikan}

\section{Pengertian}

Pendidikan adalah usaha sadar dan terencana untuk mewujudkan suasana belajar dan proses pembelajaran agar peserta didik secara aktif mengembangkan potensi dirinya untuk memiliki kekuatan spiritual keagamaan, pengendalian diri, kepribadian, kecerdasan, akhlak mulia, serta keterampilan yang diperlukan dirinya dan masyarakat. Pendidikan meliputi pengajaran keahlian khusus, dan juga sesuatu yang tidak dapat dilihat tetapi lebih mendalam yaitu pemberian pengetahuan, pertimbangan dan kebijaksanaan. Salah satu dasar utama pendidikan adalah untuk mengajar kebudayaan melewati generasi. Pendidikan adalah wahana yang dilalui peserta didik untuk mengembangkan potensi diri dalam suatu proses pendidikan yang sesuai dengan tujuan pendidikan. (Notoatmodjo, 2013).

Dalam kamus Bahasa Indonesia dinyatakan bahwa pendidikan adalah proses pengubahan sikap dan perilaku seseorang atau kelompok orang dalam usaha mendewasakan manusia melalui pengajaran dan pelatihan. (Fajri, 2000)

Menurut UU No.20 tahun 2003 dinyatakan bahwa pendidikan adalah usaha sadar dan terencana untuk mewujudkan suasana belajar dan proses pembelajaran agar peserta didik secara aktif mengembangkan potensi dirinya untuk memiliki kekuatan spiritual keagamaan, pengendalian dirinya, kepribadian, kecerdasan, akhlak mulia, serta keterampilan yang diperlukan dirinya, masyarakat, bangsa dan Negara. (Hasbullah, 2014).

Pendidikan sering diartikan sebagai usaha manusia untuk membina kepribadiannya sesuai dengan nilai-nilai dalam masyarakat dan kebudayaan. Selanjutnya pendidikan diartikan sebagai usaha yang dijalankan oleh seseorang atau kelompok orang lain agar menjadi dewasa atau mencapai tingkat hidup yang lebih tinggi dalam arti mental. Kenyataannya pengertian pendidikan ini selalu mengalami perkembangan, meskipun secara esensial tidak jauh berbeda. (Hasbullah, 2014).

Pendidikan merupakan persoalan asasi bagi manusia. Manusia sebagai makhluk yang dapat dididik akan tumbuh menjadi manusia dewasa dengan proses pendidikan dialaminya. Sejak kelahirannya, manusia telah memiliki potensi dasar yang universal, berupa: (Hasbullah, 2014).

a. Kemampuan untuk membedakan antara yang baik dan yang buruk (moral identity).

b. Kemampuan dan kebebasan untuk memperkembangkan diri sendiri sesuai dengan pembawaan dan cita-citanya (individual identity).

c. Kemampuan untuk berhubungan dan kerjasama dengan orang lain (social identity).

d. Adanya cirri-ciri khas yang mampu membedakan dirinya dengan orang lain (individual differences).

2. Pendidikan menurut jenisnya terbagi atas: (Hasbullah, 2014).

a. Pendidikan formal yaitu sebagai pendidikan yang memakai dasar suatau kurikulum atau sering disebut sebagai 
lembaga pendidikan sekolah. Yang dimaksud pendidikan sekolah disini adalah pendidikan yang diperoleh seseorang secara teratur, sistematis, bertingkat, dan dengan mengikuti syarat-syarat yang jelas dan ketat mulai dari Taman kanak-kanak (TK) sampai Perguruan tinggi.

b. Pendidikan non formal yaitu pendidikan yang tidak memerlukan kurikulum khusus, walaupun direncanakan dengan baik dan diselenggarakan diruang kelas, fleksibel dalam waktu, ruang, pengelolaan dan evaluasinya. Pendidikan dilingkungan ini memberikan bekal praktis dalam berbagai jenis pekerjaan kepada peserta didik yang tidak sempat melanjutkan proses belajarnya melalui jalur formal dan diberikan sertifikat bagi peserta yang memenuhi syarat.

c. Pendidikan informal yaitu pendidikan yang menjadi ditengah-tengah keluarga dan masyarakat. Pada pendidikan ini terjadi proses pengajaran pemberitahuan, nasihat, disiplin. Yang paling penting adalah terjadinya transfer nilai-nilai kehidupan, nilai relasi dan kebaikan.

3. Jenjang Pendidikan

Menurut UU No.2 Tahun 1989, bahwa jenjang pendidikan yang termasuk jalur pendidikan formal terdidi dari:

a. Pendidikan dasar yaitu SD ( sekolah dasar)/Madrasah ibtidaiyah dan SMP/MTs.

b. Pendidikan Menengah yaitu SMU dan Kejuruan/Madrasah Aliyah.

c. Pendidikan Tinggi yaitu Akademik, Institusi, Sekolah Tinggi dan Universitas. Bloom B (1908) dalam tujuan pendidikan menempatkan pengetahuan, sikap, dan perilaku atau tindakan menjadi 3 domain yang saling berkaitan. Penelitian menjelaskan bahwa ada hubungan langsung antara tingkat pendidikan terutama pendidikan keluarga dengan kesehatan keluarga. (Notoatmodjo, 2013).

Dalam penelitian ini Pendidikan yang dimaksud adalah tingkat pendidikan formal dimana makin tinggi tingkat pendidikan keluarga diharapkan dapat mengembangkan daya nalar dan dapat memberikan kemampuan baginya untuk menilai apakah sesuatau hal dapat diterima atau tidak. Hal ini sesuai dengan penelitian yang ditujukkan oleh Sabri (2007) bahwa makin tinggi pengetahuan keluarga semakin menurun pula tingkat kejadian ISPA. (Sabri, 2007).

Pendidikan dapat mewujutkan hubungan yang erat dengan factor resiko kesehatan (Winkleby, 1992; Brown, 1995). Tingkat Pendidikan mempengaruhi,pendapatan, penyerapan informasi, kemampuan memecahkan masalah, system nilai dan gaya hidup. Orang yang memiliki tingkat pendidikan lebih tinggi seringkali lebih mudah mengikuti program kesehatan dan pemilihan peningkatan kesehatan. Rendahnya tingkat pendidikan mengakibatkan mereka sulit menerima penyuluhan yang diberikan oleh tenaga penyuluh.

\section{E. Tinjauan Tentang pengetahuan}

1. Pengertian Pengetahuan

Menurut Notoatmodjo, 2003 dalam Wawan A, Dewi M (2011) pengetahuan merupakan hasil dari tahu dan ini terjadi setelah orang melakukan pengindraan terhadap obyek tertentu. Pengindraan terjadi melalui panca indra manusia, yakni indra penglihatan, pendengaran, penciuman, rasa dan raba. Sebagian besar pengetahuan manusia diperoleh melalui mata dan telinga. Pengetahuan atau kognitif merupakan dominan yang sangat penting untuk terbentuknya tindakan seseorang. Pengetahuan berkaitan erat dengan perilaku manusia, yaitu sebagai bentuk interaksi dan pengalaman individu dengan lingkungan.

2. Tingkat Pengetahuan

Pengetahuan yang dicakup dalam domain kognitif mempunyai enam tingkatan yaitu :

a. Tahu (know)

Tahu diartikan sebagai mengingat suatu materi yang dipelajari sebelumnya. Termasuk dalam pengetahuan tingkat ini adalah mengingat kembali (recall) sesuatu yang spesifik dari semua bahan yang dipelajari atau rangsangan yang telah diterima. Oleh sebab itu, "tahu" merupakan tingkat pengetahuan yang paling rendah. Kata kerja untuk mengukur bahwa orang tahu tentang apa yang dipelajari antara lain : menyebutkan, menguraikan, mendefenisikan, menyatakan dan sebagainya.

b. Memahani (comprehension)

Memahami diartikan sebagai suatu kemampuan untuk menjelaskan secara benar tentang objek yang ingin diketahui, dan dapat menginterpretasikan materi dengan 
benar. Orang telah paham tentang objek atau materi harus dapat menjelaskan, menyebutkan contoh, menyimpulkan, meramalkan dan sebagai terhadap objek yang dipelajari.

c. Aplikasi (application)

Aplikasi diartikan sebagai kemampuan untuk menggunakan materi yang telah dipelajari pada situasi dan kondisi sebenarnya. Aplikasi disini dapat diartikan sebagai aplikasi atau penggunaan hukumhukum, rumus, metode prinsip dan sebagainya dalam komteks atau situasi yang lain.

d. Analisa (analysis)

Analisa adalah suatu kemampuan untuk menjabarkan materi atau suatu objek kedalam komponen-komponen, tetapi masih di dalam satu struktur organisasi dan masih ada kaitannya satu sama lain. Kemampuan analisis ini dapat dilihat dari penggunaan kata kerja, seperti dapat menggambarkan (membuat logam), membedakan, memisahkan, mengelompokkan dan sebagainya.

e. Sintesis (shyntesis)

Sintesis menunjukkan terhadap suatu kemampuan untuk meletakkan atau menghubungkan bahian-bagian di dalam suatu bentuk keseluruhan yang baru. Dengan kata lain sintesis itu suatu kemampuan untuk menyusun formulasi baru dari formulasiformulasi yang ada.

f. Evaluasi (evaluation)

Evaluasi ini berkaitan dengan kemampuan untuk melakukan justifikasi atau penelitian dalam suatu materi atau objek. Penilaian-penilaian ini berdasarkan suatu criteria yang ditentukan sendiri atau menggunakan kriteria-kriteria yang ada.

Mengukur pengetahuan dapat dilakukan dengan wawancara atau angket yang menanyakan tentang isi materi yang ingin diukur dari subyek penelitian atau responden. Kedalaman pengetahuan yang ingin kita ketahui atau kita ukur dapat disesuaikan dengan tingkattingkat tersebut diatas. Mengukur pengetahuan seseorang tentang apapun hanya dapat diukur dengan membandingkan orang tersebut dalam kelompoknya dalam arti luas. (Notoatmodjo, 2013). 3. Faktor-faktor yang mempengaruhi
pengetahuan
Faktor-faktor yang mempengaruhi pengetahuan seseorang adalah; (Notoatmodjo, 2013).

a. Faktor internal: faktor dari dalam diri sendiri, misalnya; intelegensi, emosi dan kondisi fisik

b. Faktor eksternal: faktor dari luar diri, misalnya; keluarga, masyarakat dan sarana serta faktor pendekatan belajar seperti upayah belajar, misalnya strategi dan metode dalam pembelajaran.

Secara tidak langsung pengetahuan seseorang dipengaruhi oleh tingkat pendikan, namun tidak berarti tingkat pendidikan yang rendah pengetahuannya juga rendah, karena pengetahuan dapat diperoleh dimana saja dan kapan saja tanpa melalui pendidikan formal yaitu melalui media masa dan elektronik (TV, radio, dll) sehingga pengetahuan seseorang dapat bertambah tinggi, termasuk pengetahuan tentang perawatan kesehatan. Sesuai dengan pendapat dari I B Mantra (1994) yang dikutip oleh Sentana bahwa makin tinggi pendidikan seseorang makin mudah seseorang tersebut untuk menerima informasi. Dengan pendidikan tinggi maka seseorang akan cenderung untuk mendapatkan informasi, baik dari orang lain maupun dari media massa, semakin banyak informasi yang masuk semakin banyak pula pengetahuan yang didapat tentang kesehatan. Pengetahuan tentang kesehatan semakin banyak maka usaha untuk memelihara derajat kesehatannya semakin optimal.

Hal ini sejalan dengan penelitian yang dilakukan oleh Suroso (1986), bahwa rendahnya tingkat pendidikan akan menghambat tingkat pembangunan seseorang yang mempunyai latar belakang pendidikan yang rendah akan mengalami kesulitan untuk menerima konsep kejadian penyakit serta upayah pencegahan penyakit.

\section{Metode Penelitian}

Penelitian ini menggunakan metode deskriptif analitik dengan rancangan cross sectionalstudy yang bertujuan untuk mencari hubungan antara variabel dependen dan variabel independen yang diamati pada periode waktu yang sama untuk melihat hubungan antara tingkat pendidikan dan tingkat pengetahuan ibu dengan kejadian ISPA pada balita di wilayah kerja Puskesmas Bontisikuyu Kabupaten Kepulauan Selayar. (Nursalam, 2011).

\section{Populasi}

Populasi adalah subjek yang memenuhi kriteria yang telah ditetapkan (Nursalam, 2011). Populasi dalam penelitian ini adalah semua ibu yang memiliki Balita usia 12 - 59 bulan yang terdiagnosa ISPA 
beradasarkan buku pencatatan yang ada di Puskesmas Bontisikuyu Kabupaten Kepulauan Selayar sejak 3 bulan lalu sampai sekarang. Adapun jumlah populasinya sebanyak 190 orang.

\section{Sampel dan Sampling}

Sampel merupakan bagian dari populasi terjangkau yang dapat dipergunakan sebagai subjek penelitian. Penentuan jumlah sampel pada penelitian ini dilakukan dengan menggunakan teknik sampling Purporsive sampling yaitu bentuk pengambilan sampel berdasarkan pertimbangan tertentu (Nursalam, 2011). Dimana jumlah populasi adalah 190 orang, dikehendaki tingkat ketelitian $5 \%$ atau tingkat kesalahan 5\% sehingga jumlah sampel yang diperlukan adalah 123 orang responden. (Sugiyono, 2014).

\section{Hasil Penelitian Dan Pembahasan Hasil Penelitian}

Penelitian ini dilaksanakan diwilayah kerja Puskesmas Bontosikuyu Kabupaten Kepulauan Selayar. Pengambilan sampel dilakukan dengan teknik Accidental sampling yaitu suatu teknik penetapan sampel dengan Kebetulan bertemu. Banyaknya sampel yang digunakan sebanyak 30 orang.

Data primer diambil melalui teknik wawancara berstruktur dan observasi langsung yang dilakukan pada responden. Dari hasil pengolahan data yang dilakukan, maka hasil penelitian dapat disajikan sebagai berikut :

\section{Analisa Univariat}

Analisa univariat bertujuan untuk memperlihatkan atau menjelaskan distribusi frekuensi dari variabel independen dan variabel dependen. Analisa univariat dalam penelitian ini dapat dijelaskan sebagai berikut:

a. Kejadian ISPA

Menunjukan bahwa dari 30 responden yang diteliti, yang menderita ISPA sebanyak 20 orang $(67 \%)$ dan tidak menderita ISPA sebanyak 10 0rang (33 $\%)$

b. Tingkat Pendidikan Ibu Menunjukan bahwa dari 30 responden yang diteliti, Ibu yang berpendidikan $\geq$ SMA sebanyak 9 orang $(30 \%)$ dan yang berpendidikan $<$ SMA sebanyak 21 Orang $(70 \%)$

c. Tingkat Pengetahuam

Menunjukan bahwa dari 30 responden yang diteliti, Ibu yang berpengetahuan baik sebanyak 9 orang (30\%) dan yang berpengetahuan kurang baik sebanyak 21 Orang $(70 \%)$

2. Analisa Bivariat
Analisa bivariat dilakukan untuk melihat hubungan variable bebas dan variable tergantung, dengan menggunakan uji statistic Chi-square dan tingkat kemaknaan yang dipilih adalah $\alpha=0,05$ dengan menggunakan program SPSS versi 16,0 for windows.

Analisa bivariat dalam penelitian ini dapat dijelaskan sebagai berikut:

Hubungan tingkat Pendidikan ibu dengan Kejadian ISPA

Menunjukan bahwa jumlah ibu berpendidikan $\geq$ SMA dan anaknya tidak mengalami Ispa sebanyak 9 orang (30\%), Ibu yang berpendidikan $\geq$ SMA dan anaknya tidak mengalami Ispa tidak ada. Ibu yang berpendidikan <SMA dan anaknya mengalami Ispa sebanyak 10 orang (33\%), Ibu yang berpendidikan <SMA dan anankya tidak menderita ISPA sebanyak 11 orang $(37 \%)$ orang.

Hasil uji Chi-square test pada variable ini adalah $\rho=$ 0.06, lebih besar dari tingkat kemaknaan yang ditentukan yaitu $\alpha=0.05$ Sehingga menunjukan bahwa tidak ada hubungan antara tingkat pendidikan ibu dengan Kejadian ISPA Pada Balita diwilayah kerja Puskesmas Bontosikuyu Kabupaten Kepulauan Selayar.

\section{Tingkat Pengetahuan Ibu dengan Kejadian ISPA}

Menunjukan bahwa jumlah Ibu yang berpengetahuan baik dan anaknya menderita ISPA sebanyak 2 orang (11\%), Ibu yang berpengetahuan baik dan anaknya menderita ISPA sebanyak 7 orang (64\%), Ibu yang berpengetahuan kurang baik dan anaknya tidak menderita ISPA sebanyak 17 orang (89\%), Ibu yang berpengetahuan kurang baik dan anaknya tidak menderita Ispa sebanyak 4 orang (36\%).

Hasil uji Chi-square test pada variable ini adalah $\rho=$ 0.004, lebih kecil dari tingkat kemaknaan yang ditentukan yaitu $\alpha=0.05$ Sehingga menunjukan bahwa ada hubungan antara tingkat pegetahuan Ibu dengan Kejadian ISPA pada Balita diwilayah kerja Puskesmas Bontosikuyu Kabupaten Kepulauan Selayar.

\section{Pembahasan.}

Berdasarkan hasil pengolahan data yang dilakukan dan disesuaikan dengan tujuan penelitian yaitu diketahui hubungan tingkat pendidikan ibu dengan tingkat pengetahuan ibu dengan Kejadian ISPA pada Balita diwilayah kerja Puskesmas Bontosikuyu Kabupaten Kepulauan Selayar, maka pembahasan hasil penelitian ini diuraikan sebagai berikut:

\section{Tingkat Pendidikan Ibu}

Hasil penelitian menunjukan bahwa jumlah Ibu yang berpendidikan kurang dan anaknya tidak menderita ISPA sebanyak 3 orang $(10,0 \%)$, Ibu yang berpendidikan kurang dan anaknya menderita ISPA sebanyak 18 orang $(60,0 \%)$, Ibu yang berpendidikan 
cukup dan anaknya tidak menderita ISPA sebanyak 7 orang $(23,3 \%)$ dan Ibu yang berpendidikan cukup dan anaknya menderita ISPA sebanyak 2 orang $(6,7$ $\%)$

Hasil uji Chi-square test pada variable ini adalah $\rho=0.002$, lebih kecil dari tingkat kemaknaan yang ditentukan yaitu $\alpha=0.05$ Sehingga menunjukan bahwa ada pengaruh antara Pendidikan Ibu dengan Kejadian ISPA pada Balita di Puskesmas Batua Kecamatan Panakkukang Kota Makassar

Menurut H.R. Ngatimin (2007) tingkat pendidikan merupakan dasar perkembangan dari daya nalar seseorang dengan jalan memudahkan seseorang untuk menerima motivasi. Pendidikan memegang peranan penting dalam meningkatkan pengetahuan masyarakat tentang pentingnya kesehatan. Pendidikan yang telah dicapai oleh penduduk juga dapat digunakan sebagai salah satu indikator untuk mengukur tingkat kesejahteraan masyarakat dan juga sangat berperan dalam menurunkan angka kesakitan.

M. Tahir Abdullah (2008) mengatakan bahwa ibu yang berpendidikan tinggi lebih mudah menerima ide baru atau mudah menerima pesan dan mudah terjadi pergeseran nilai-nilai baru karena pada pendidikan yang tinggi tidak sekuat memegang nilainilai lama dibanding dengan pendidikan yang lebih rendah.

\section{Tingkat Pengetahuan Ibu}

Berdasarkan hasil penelitian bahwa jumlah Ibu yang berpengetahuan baik dan anaknya menderita ISPA sebanyak 2 orang (11\%), Ibu yang berpengetahuan baik dan anaknya menderita ISPA sebanyak 7 orang (64\%), Ibu yang berpengetahuan kurang baik dan anaknya tidak menderita ISPA sebanyak 17 orang (89\%), Ibu yang berpengetahuan kurang baik dan anaknya tidak menderita Ispa sebanyak 4 orang $(36 \%)$.

Hasil uji Chi-square test pada variable ini adalah $\rho=0.004$, lebih kecil dari tingkat kemaknaan yang ditentukan yaitu $\alpha=0.05$ Sehingga menunjukan bahwa ada hubungan antara tingkat pegetahuan Ibu dengan Kejadian ISPA pada Balita diwilayah kerja Puskesmas Bontosikuyu Kabupaten Kepulauan Selayar.

Pengetahuan merupakan hasil dari tahu dan ini terjadi setelah orang melakukan pengindraan terjadi melalui panca indra manusia (Efendi, 2009). Pengetahuan merupakan faktor yang sangat penting dalam membentuk tindakan seseorang (over behavior).

Menurut Syahrani, Santoso dan Sayono (2012) pengetahuan seseorang tentang sesuatu objek juga mengandung dua aspek yaitu aspek positif dan negatif. Kedua aspek inilah yang akhirnya akan menentukan sikap seseorang terhadap objek tertentu. Semakin banyak aspek positif dari objek yang diketahui, akan menumbuhkan sikap makin positif terhadap objek tersebut. Pengetahuan dapat mendorong seseorang untuk berusaha memperoleh informasi lebih banyak mengenai sesuatu yang dianggap perlu dipahami lebih lanjut atau dianggap penting. Ibu sebagai pemegang peran pengasuh bagi anak wajib mengetahui segala keperluan dan kekurangan yang belum terpenuhi pada anak.

Hal ini mendorong orang tua (ibu) untuk mengembangkan sikap yang menuntun pada tindakan sebagai hasil atau output dari pengetahuan terhadap hal - hal yang berhak diperoleh anak salah satunya adalah perawatan.

Pernyataan ini didukung oleh hasil penelitian Kurniasih (2009), bahwa ada hubungan yang signifikan antara tingkat pengetahuan ibu dengan upaya perawatan terhadap balita dengan ISPA. Hal ini diperkuat oleh pendapat Notosiswoyo dalam Syahrani, Santoso \& Sayono (2012) bahwa rendahnya tingkat pengetahuan dan keterampilan keluarga terutama ibu menjadi salah satu pemicu terjadinya ISPA pada balita.

Sebagian besar keluarga yang mempunyai balita ISPA dirumah adalah ibu yang tidak mengetahui cara mencegah ISPA. Berdasarkan hasil penelitian di Puskesmas Bahu menunjukkan bahwa responden memiliki pengetahuan baik terhadap perawatan balita dengan ISPA.

Hal ini sesuai dengan hasil penelitian Haerani (2007) didapatkan bahwa terdapat hubungan yang bermakna antara pengetahuan dengan perilaku ibu merawat balita yang menderita ISPA di Kelurahan Tlogosari Wetan Semarang.

Seperti yang diungkapkan oleh Syahrani, Santoso \& Sayono (2012) bahwa tingkat pengetahuan seseorang yang semakin tinggi akan berdampak pada arah yang lebih baik. Sehingga ibu yang berpengetahuan baik akan lebih objektif dan terbuka wawasannya dalam mengambil suatu keputusan atau tindakan yang positif terutama dalam hal memberikan perawatan pada balita yang sakit terutama ISPA.

\section{Kesimpulan}

Dari hasil penelitian diwilayah kerja Puskesmas Bontosikuyu Kabupaten Kepulauan Selayar, maka dapat disimpulkan sebagai berikut :Tida ada hubugan antara tingkat pendidikan ibu dengan kejadian ISPA pada Balita diwilayah kerja Puskesmas Bontosikuyu Kabupaten Kepulauan Selayar. Ada hubungan antara tingkat pengetahuan ibu dengan kejadian ISPA pada Balita diwilayah kerja Puskesmas Bontosikuyu Kabupaten Kepulauan Selayar.

\section{Saran}

Berdasarkan kesimpulan diatas penulis dapat memberikan saran sebagai berikut: Perlunya penyebarluasan informasi tentang ISPA agar masyarakat senantiasa tidak membiarkan anaknya terpapar dengan factor risiko ISPA, Perlunya 
kesadaran dari orang tua agar senenatiasa menjaga lingkungan rumah karena akan mempengaruhi kesehatan pada Balita sehingga harus dilakukan Sosialisasi bahaya lingkungan pada masyarakat oleh petugas kesehatan setempat,Agar Pihak Institusi Pendidikan menyediakan waktu khusus untuk mengadakan penelitian sehingga data yang didapatkan di lapangan betul-betul akurat, Melihat tingginya kejadian ISPA pada balita di Puskesmas Bontosikuyu Kabupaten Kepulauan Selayar, maka perlu dilakukan penelitian ulang bagi peneliti yang berminat dengan instrumen dan pengukuran yang tepat sehingga dapat diperoleh hasil penelitian yang optimal.

\section{DAFTAR PUSTAKA}

Achmad,M.A, (2006). Factor yang berhubungan dengan kejadian ispa pada balita di desa bontomaranu kec. Galesong selatan kab. Takalar 2006. Skripsi tidak diterbitkan. FK-kep. Unhas, makassar.

Depkes.RI (2015). Pedoman pemberantasan penyakit ispa pada anak. jakarta.

Depkes RI, (2014). Buku kesehatan ibu dan anak. Jakarta.

Didin, (2016). Infeksi Saluran Nafas Akut (ISPA) (on line). Http://www. Halal Guide .INFO - Guide to Halal and Islamic Lifestyle,.htm. diakses tgl 10-10-2016

Dinkes Provinsi Sul-sel (2015). Profil kes. prov.sulsel 2015.

Dinkes kota yogyakarta, (2005). Info penyakit (on line) Http://www. Dinas kesehatan pemerintah kota yogyakarta (penyakit ispa).htm. diakses tgl 10-10-2016

Ditjen PPM\&PL (2012). Info penyakit menular (on line) Http://www. Dinas kesehatan dki jakarta penyakit.htm. diakses tgl 10-12-2016

Fajri,E.Z. (2000).Kamus lengkap Bahasa Indonesia. Difa Publisher, Jakarta.

Hasbullah, (2014). Dasar-dasar ilmu pendidikan, edisi I. PT. Raja Grafindo Persada, Jakarta

Hidayat, A.A (2013). Metode penelitian keperawatan dan teknik analisis data. Salemba medika, Jakarta. 49-50,74,82-83

Kartini,T (2002). Hubungan antara pengetahuan dan sikap ibu dalam memberikan perawatan penunjang di rumah pada anak ( usia 2 bulan 5 tahun) yang menderita ispadi puskesmas wonoayu,sidoarjo (on line). Http://www. Itb central library - welcome powered by gdl4_2.htm, diakses tgl 10-10-2016

Laporan tahunan Puskesmas Bontisikuyu Kabupaten Kepulauan Selayar 2016.

Mardianah, (2003). Hubungan kondisi rumah dengan kejadian ispa pada balita di kelurahan bara- baraya kota makassar tahun 2003, kripsi tidak di terbitkan. FKM Unhas Makassar.

Ngastiyah, (1999). Perawatan anak sakit. EGC, Jakarta. 9-16

Notoatmodjo,S, (2013). Ilmu kesehatan masyarakat prinsip-prinsip dasar,.Rineka Cipta,Jakarta.127130

Nursalam, (2011). Metode Penelitian Kesehatan. Rineka Cipta,Jakarta

Peduli kasih, (2013). Waspadai ispa (on line).Http://www. indosiar dot com - PEDULI KASIH.htm. diakses tgl 10-10-2016

Rasmaliah, (2004). Infeksi saluran pernafasan akut (ispa) dan penanggulangannya (on line). Http://www. Fkm-Rasmaliah-Infeksi saluran pernafasan akut(ispa) dan penanggulangannya.pdf. diakses tgl 10-10-2016

Sabri, (2007). Skripsi tentang faktor-faktor yang berhubungan dengan kejadian Ispa di puskesmas Antang 2007. Skripsi tidak di terbitkan. Stik gia Makassar.

Sugiyono, (2014). Metode penelitian administrasi. Alfabeta, Jakarta.

Sunaryo, (2014). Psikologi untuk keperawatan. EGC, Jakarta. 25-27.

Supartini, Y (2014). Buku ajar konsep dasar keperawatan anak. EGC,Jakarta. 46.

Widjaja, (2013). Penanganan ispa pada anak di rumah sakit kecil Negara berkembang. EGC, Jakarta.

Wawan, A, Dewi M. 2011. Teori \&Pengukuran Pengetahuan, Sikap, dan Perilaku Manusia.Cetakan II.Nuha Medika: Yogyakarta. 